\title{
Sustained Release Pellet Capsule Dosage Form
}

National Cancer Institute

\section{Source}

National Cancer Institute. Sustained Release Pellet Capsule Dosage Form. NCI

Thesaurus. Code C68947.

A capsule composed of active and/or inert ing redient(s) small, spherical structures that contain active and/or inert ing redient(s) encased within a shell. It is designed to release ingredients slowly so as to achieve a constant circulating concentration of the ingredient over a period of time. 